\title{
Needed Competencies and Strategies for Improving Teaching of Home Economics Education in Kaduna State
}

\author{
Funmilayo Alabi \\ Home Economics Department \\ Federal College of Education, Zaria-Nigeria
}

\section{Doi:10.5901/jesr.2013.v3n9p73}

\begin{abstract}
This paper focuses on competencies needed by N.C.E. and B.Ed Home Economics graduates in Kaduna State. It deals with needed competencies, constrains, and the way students could be helped to acquire the necessary competencies. Three research questions were answered. The sample was made up of the total population of 660 students of Home Economics who are into business. The finding revealed inter alia 15 needed competencies, 9 constraints that could hinder student's competency and 7 ways of helping students acquire the necessary competencies and recommendations were made.
\end{abstract}

Keywords: Competencies, Strategies and Home Economics.

\section{Introduction}

The goal of Home Economics as a vocational subject is to equip students with all the pertinent practical knowledge and social skills necessary for them to take a productive role in the economy. A teacher of Home Economics education also has the sole responsibility of impacting these knowledge and skills to students in the subject area. The teacher implements curriculum, motivates learning, facilitates learning and guides learning in Home Economics for the benefit of the students and society.

Nigeria as a Nation has great human and material resources but it is bedeviled by a number of problems such as underemployment, unemployment, poverty and rapid technological development. According to UNICEF (2002), wide spread of poverty, hunger and unemployment is an enduring problem affecting an estimated 800 million people worldwide and it is a factor responsible for at least five 5 million death each year. Apparently these problems are connected to the fact that learners are prepared for employment and not necessarily for job creation. Olaitan, Nwachuku, Oyemachi, Igbo and Ekong (1999) opined that Home Economics has low effectiveness because the program is not job oriented but are based on theoretical foundations of available textbooks and teachers back ground.

Creak Training Centre (2001) argued that as long as the majority of Nigerians remain without adequate knowledge and skills needed to develop the various sectors of the economy, unemployment and underdevelopment will prevail. The reality of the situation of our society today is that vocational subjects like Home Economics have not been able to attain this laudable goal of skilled man power that provide self-employment.

Furthermore Aguasim (1995) rightly observed that praxeology is the key to vocational education especially vocational Home Economics and most other purposeful education at all level while practice without praxeology will usually have adverse effects since it is not based on theory. It is therefore more appropriate for students to have adequate exposure to both theory and practical aspects of the course.

Adequate competencies are needed by graduate of Home Economics in order to be self- 
employed. Competency is a successful performance of a task through the use of knowledge, skills attitude and judgment (Olaitan and Ali 1997). Competency based Home Economics Education becomes more important with the need to reduce unemployment and promote self-employment. With competency based Home Economics Education, Home Economics students will become more competent and empowered.

The competencies needed by students when possessed and utilized with help students to become self-employed earing will be enhanced and poverty is reduced. It is against this background that this article seeks to identify competencies needed for improving teaching and learning of Home Economics with the view to proffering suggestions that could improve the teaching and learning of Home Economics.

\section{Purpose of the Study}

The main purpose of this study was to investigate needed competencies and the strategies for improving teaching of Home Economics in Kaduna State.

Specifically the study determined:

i. Competency needed by the students of Home Economics

ii. Constraints in acquiring the competency

iii. Ways of helping students acquire the necessary competencies.

\section{Research Questions}

- What are the competencies required by graduates of Home Economics to become selfemployed.

- What are the constraints in acquiring the needed competencies.

- How can the students be helped to acquire the needed competencies

\section{Design/Area of Study}

This study employed descriptive survey research type to find out the competencies needed by Home Economic students to become self-employed.

According to Kerlinger (2004) survey research is a useful tool employed by the researcher when they are interested in the opinion and attitudes of people.

The questionnaire is divided into three sections and each section tests the research questions. In section one there are twenty questions, eleven in section two and seven in section three. The area of study was Kaduna State; it is located at the center of Northern Nigeria. It shared boundaries with Niger state Plateau state, F.C.T. Zamfara and Katsina.

\section{Population of the Study}

The population of the study was N.C.E and B.Ed graduates of Home Economics in the area of the study. The entire population was studied. The respondents were all self-employed in twelve identified small scale enterprises zoned into two areas i.e. residential and commercial zones.

\section{Sample}

The sample for the study was made up of N.C.E. and B.Ed graduates that are in business. All the 660 that were self-employed was selected. 


\section{Instrument for Data Collection}

A four point scale of Highly Needed, Averagely Needed, Slightly Needed and Not Needed was used for section one, while Strongly Agree, Agreed, Disagreed and Strongly Disagreed was used for the remaining two sections. Any item whose mean value is 2.50 and above was regarded as Needed and Agreed while below 2.50 was regarded as Not needed and disagreed.

\section{Validation}

The instrument was validated by two experts in the field of Home Economics before being used for data collection.

\section{Reliability}

The reliability of the instrument was determined using Crombach Alpha and reliability coefficient of 0.87 was obtained.

\section{Data Collection and Analysis Technique}

A total of six hundred and sixty (660) copies were administered, 648 were completed and retrieved this represent $98 \%$ return. Mean score was used for data analysis and to answer the research questions. The cutoff point of 2.5 was used.

Table I: Needed Competencies by Graduate Students of Home Economics

\begin{tabular}{|c|l|c|c|}
\hline \multicolumn{1}{|c|}{ Questionnaires Items } & Mean & Remark \\
\hline 1 & Need to learn how to set up a standard restaurant & 3.79 & Needed \\
\hline 2. & Need to develop critical thinking and problem solving skills & 3.72 & Needed \\
\hline 3. & Need adequate knowledge on how to raise money for funding business & 4.49 & Needed \\
\hline 4. & Need to perfect cake baking & 2.31 & Not needed \\
\hline 5. & Need to perfect icing of cake & 3.20 & Needed \\
\hline 6. & Need to know how to use the computer in combining colours in food & 5.0 & Needed \\
\hline 7. & Need to perfect pattern drafting & 2.3 & Not needed \\
\hline 8. & Need to perfect free hand cutting & 5.0 & Needed \\
\hline 9. & Perfect how to produce fast dye Batik and tie and dye & 4.2 & Needed \\
\hline 10. & Need to perfect bead making & 3.3 & Needed \\
\hline 11. & $\begin{array}{l}\text { Need to be able to use the computer in constructing patterns and combing } \\
\text { different colours }\end{array}$ & 5.0 & Needed \\
\hline 12. & $\begin{array}{l}\text { Need to be able to use computer in production and grading of dress patters } \\
\text { for commercial and large scale production. }\end{array}$ & 4.8 & Needed \\
\hline 13. & Need to know how to run a catering services (cooking for events) & 4.7 & Needed \\
\hline 14. Interior Decoration (Sewing of curtains and blinds, decoration of cushions) & 2.1 & Not needed \\
\hline 15. & $\begin{array}{l}\text { Need to know how to arrange funeral event (decoration of beds, parlor, } \\
\text { making of wreaths, decorations of canopies) }\end{array}$ & 4.8 & Needed \\
\hline 16. & Need to know how to make embroidery on clothes & 4.0 & Needed \\
\hline 17. & Need to know how to make models and toys & 4.3 & Needed \\
\hline 18. & Need to know how to make laundry and dry cleaning & 3.8 & Needed \\
\hline 19. & Need to know how to make soap and detergent making & 4.1 & Needed \\
\hline 20. & Need to develop managerial skills & 4.6 & Needed \\
\hline
\end{tabular}

Table 1 revels that seventeen out of twenty items were needed competency, and items 4, 7 and 15 were the not needed competencies with a mean score below 2.5. 
Table 2: Constraints that could Affect the Attainment of Competency by Students

\begin{tabular}{|c|l|c|c|}
\hline \multicolumn{1}{|c|}{ Questionnaires Items } & Mean & Remark \\
\hline 1 & \multicolumn{1}{|c|}{ Inadequate infrastructure } & 3.2 & Agreed \\
\hline 2. & Insufficient equipment and funding & 3.7 & Agreed \\
\hline 3. & No enough time for theory & 2.3 & agreed \\
\hline 4. & No enough use of demonstration method & 3.6 & Agreed \\
\hline 5. & No enough time for practical's & 3.9 & Agreed \\
\hline 6. & No qualified teachers & 2.1 & Disagreed \\
\hline 7. & $\begin{array}{l}\text { Teachers need constant retraining from time to time because of constant } \\
\text { advancement in technology }\end{array}$ & 4.5 & Agreed \\
\hline 8. & Inadequate I.C.T knowledge and the part of the teachers and the students. \\
\hline 9. & Inadequate funding & 4.5 & Agreed \\
\hline 10. & Lack of managerial skills & 4.2 & Agreed \\
\hline 11. & No knowledge or problem solving skills and critical thinking & 4.7 & Agreed \\
\hline
\end{tabular}

Table 2 shows that two out of the eleven items were disagreed upon by the respondents as not been constraints they are item 3 and 6, these items had a mean score below 2.50 while the remaining 9 items were agreed on as constraints to students competency.

Table 3: Possible ways of helping students acquire the necessary competencies.

\begin{tabular}{|l|l|c|c|}
\hline \multicolumn{1}{|c|}{ Items } & Mean & Remark \\
\hline 1. & $\begin{array}{l}\text { Teachers are to be re-trained in their area of specialization from time to time for } \\
\text { teachers and students up-dating. }\end{array}$ & 4.2 & Agreed \\
\hline 2. & Practical and theory should all be emphasize & 3.8 & Agreed \\
\hline 3. & Demonstration of each skill should be carried out to build competency. & 4.0 & Agreed \\
\hline 4. Students should be able to practice each of the skills on their own before graduation & 4.7 & Agreed \\
\hline 5. Both teachers and students should be computer savvy & 4.6 & Agreed \\
\hline 6. Students should be able to master managerial skills & 4.9 & Agreed \\
\hline 7. Attend seminars, workshop and conferences. & 4.8 & Agreed \\
\hline
\end{tabular}

Table 3 reveals that all the seven items were agreed on as ways students could be helped to acquire needed competencies before graduation.

\section{Discussion}

Findings from the study reveals in table 1 that the respondents agreed on seventeen items as the needed competencies required, four out of the items had mean response which is below 2.5. these are: cake baking, perfect pattern drafting, perfect sewing of curtains blind and decorate cushions, for enough time for theory: while the needed competencies are: set up and manage standard restaurant, know how to raise fund for the business, perfect icing of cake, knowledge or computer for teaching both food and clothing, have managerial skills, perfect making of tie and dyes, beads making, know how to carry out outdoor catering services, manage funeral events, perfect making of models, toys, laundry and dry cleaning. The findings agree with Anyakoha (2001) noted that Home Economics must be ready to learn, acquire new knowledge, skills and apply their new acquisition for solution of the problems that challenge the family. Home Economist must be alert to societal problems and changes like unemployment and must keep abreast science and technology.

Table 2 reveals that eight items scored above 2.5 expect two items which scored less than 2.5 and that reveals that qualified teachers are on ground and that there is enough time for the theoretical aspect of the course. The eight items that scored above 2.5 are inadequate infrastructure in some cases, insufficient funds and equipment for practical compare to the number 
of students, no enough time for demonstration and practical's, need for retraining of teachers and students in line with development in science, technology and I.C.T. and managerial skills and problem solving skills. All of these were agreed on by the respondents as constraints to attaining needed competencies by students. This finding is in line with survey that was carried out by lloejo and Anyawu (1991) which revealed that failure rate of small scale business set up by Home Economics students are high and this failure can be attributed to lack of adequate entrepreneurial skills critical thinking, lack of enough time for practical's.

Possible ways of helping students acquire the necessary competencies as reveals in Table 3 is that all the items were agreed upon as a way forward. Teachers have to be re-trained in their area of specialization in line with science and technology from time to time, practical's and theory should be emphasized, demonstration of each skills for the students, both teachers and students should be computer savvy, have managerial skills, and attend seminars, workshop and conferences.

Lemchi (2001) noted that Home Economics students need managerial skills, competency in computer, critical thinking and getting updated information from workshops.

Students can be helped to acquire necessary competencies needed to be self-employed if the above are fulfilled.

\section{Conclusion}

The study reveals the competencies needed to be improved upon by students of Home Economics, in Kaduna State, constraints that could affect the attainment of competency by students and possible ways of helping students acquire the necessary competencies.

\section{Recommendations}

1. Challenging environment that will serve as impetus for competency and skills improvement by students and teachers of Home Economic should be created and sustained by Federal Government through tertiary institutions.

2. Tertiary institutions should organize seminar and workshops for their old students to update knowledge and skills in line with science and technology.

3. Graduate students should endeavor to attend conferences, seminars and workshops to upgrade their competency and skills.

4. Government should constantly review teachers tenancy based on skill competency to ensure quality.

5. There is the need to reorganize Home Economics curriculum to have balance between knowledge and skills and values, so that the curriculum become competency based.

6. There is need to have realistic time allocated for acquiring the desired competency.

7. Soft loans should always be given to Home Economics students on graduation by banks and the government to enable them to establish small scale enterprise.

\section{References}

Anyakoha E.U (2001), Research Challenges for the Nigerian Home Economics in the $21^{\text {st }}$ Century, Research imperatives challenges for Home Economics in Nigeria. Home Economics Research Association, Nigeria Nsukka.

Agwasim B.J and Agwasim M.C (1995) Teaching Vocational Home Economics in College of Education and Universities. Port Harcourt. Basmark Publishing Company.

Creak Training Centre (2007), The Role of Technical and Vocational Education (ITVC), Organized by Education Trust Fund. Held at Abuja Sheraton Hotels and Towers.

Iloeja .C. and Anyawu G.A. (1991), Entrepreneurship and Vocational Home Economic in Nigeria. A paper at the Annual Conference of the Nigerian Vocational Association Federal College of Education (T) Umunze. 
Kerlinger F. (2004), Site Template designed by Els, Kent NGFC Oxford Road, Maidstine, MELSSAN.

Lemchi S.N. (2001), Incorporating contemporary issues into Nigerian Home Economics curriculum. Research Imperative Challenges for Home Economics in Nigeria. Home Economics Association of Nigeria.

Olaitan S.O, Nwachuku C.E., Onyemachia .G., Olgbo C.A and Ekong A.O (1999), Curriculum development and Management in Vocational Technical Education Ontisha. Cape Publication.

Olaitan and Ali (1997), The Making of Curriculum (Theory, Process, Product and Evaluation) Cape Publishers International Limited. Onitsha Nigeria.

UNICEF (2002), Facts of life communication Challenge, Shire Oxford, English. 